\title{
16
}

\section{From Measurement to Management: Food Waste in the Finnish Food Chain}

\author{
Hanna Hartikainen, Inkeri Riipi, Juha-Matti Katajajuuri \\ and Kirsi Silvennoinen
}

\section{Introduction}

The United Nations (UN) has set a target to reduce consumer and retail food waste by half and minimise overall food waste in the food chain by 2030 (UN 2016). The EU Commission is therefore about to establish a common enactment for its member states to monitor food waste in every step of the food chain (EU Commission 2018a, b). This chapter aims to present a case for developing the Finnish food waste measurement and management system. As researchers of the Natural Resources

H. Hartikainen $(\bowtie) \cdot$ I. Riipi · J.-M. Katajajuuri $\cdot$ K. Silvennoinen

Natural Resources Institute Finland, Helsinki, Finland

e-mail: hanna.hartikainen@luke.fi

I. Riipi

e-mail: inkeri.riipi@luke.fi

J.-M Katajajuuri

e-mail: juha-matti.katajajuuri@luke.fi

K. Silvennoinen

e-mail: kirsi.silvennoinen@luke.fi

(C) The Author(s) 2020 
Institute of Finland (Luke 2018d), we will discuss how the quantification of food waste may be improved to reduce it in the food chain. Luke is an active developer of Finland's measurement and management system for food waste (Luke 2018c).

It is impossible to develop food waste prevention strategies without knowledge concerning where, why and how much food is wasted in the food chain. The lack of food waste data has been generally recognised. For this reason, there have been several studies on methods to measure and manage food waste in recent decades (Møller et al. 2014). Many countries have conducted case studies on food waste, its causes and best practices for reducing it (van Herpen et al. 2016; Xue et al. 2017), and these studies provide valuable knowledge concerning the food waste data collection methods needed to monitor and manage waste levels. However, in Finland and throughout the EU, there is a lack of comparative and statistical food waste data (Xue et al. 2017). For example, many countries lack data on primary production losses (Hartikainen et al. 2018). Data representativeness is also often poor in food waste studies. Most are not representative (or the sample's representativeness is not properly discussed), and hence, it is impossible to estimate the direction food waste levels take over time (Xue et al. 2017). While published food waste studies have led to a better understanding of its magnitude, most are based on limited samples from certain areas/places and years (Xue et al. 2017). For example, in a 2011 Finnish study, 72 distinct sites in the food catering sector measured food waste (Heikkilä et al. 2016; Silvennoinen et al. 2015). The number of sites participating by weighing food waste was high compared to other catering sector food waste studies (Møller et al. 2014; Stenmarck et al. 2016) and thus gave a good insight into the magnitude of the sector's food waste. Yet the Finnish study was insufficient to provide comparative data for measuring how much food is wasted annually in the catering sector if the study were repeated.

Besides the lack of data, another major challenge is that there is no commonly accepted definition of food waste. For instance, according to the Food and Agriculture Organization (FAO), food waste refers to "discarding or alternative (non-food) use of food that is safe and nutritious for human consumption" (FAO 2018b). Meanwhile, 
the Definitional Framework for Food Waste in the FUSIONS project defines food waste as "any food, and inedible parts of food, removed from the food supply chain to be recovered or disposed" (Östergren et al. 2014). The main difference between these definitions is that under the FUSIONS definition, some non-food uses, such as feed, are not defined as waste, whereas FAO categorises all non-food uses as food waste/loss. Since there is no agreement on the terms and definitions for food waste and because there are several data gaps, it is difficult to set efficient policy measures to reduce it. The European Commission has therefore established a platform to provide further insight into measuring food waste (European Commission 2016) and consequently support the halving of food waste.

To address the aims of this chapter aim, we will describe the next steps in Finland's proactive construction of a food waste measurement system and prevention roadmap. In 2018, Finnish researchers, ministries, the food industry and retail sector, as well as other key food chain stakeholders agreed on active collaboration throughout the food chain to reduce Finnish food waste (Luke 2018c). In Finland, international developments related to food waste reduction are closely followed (European Commission 2018a, b), and there is an attempt to effectively reduce Finnish food waste. However, efficient food waste reduction requires collaboration throughout the food chain.

To manage and systematically reduce food waste, key actors from all steps in the food chain are collaborating together in order to agree upon the food waste definitions, methods for detailed and systematic food waste data collection and food waste data collection periods. Food chain actors will participate with Luke researchers in piloting carefully designed food waste quantification methods between 2018 and 2020. The ambitious aim is to build a system that enables repeatable food waste quantification in all steps of the food chain and compiles a comparative and representative food waste dataset. Previous studies demonstrate that suitable food waste evaluation methods have varied at different steps of the food chain (Hartikainen et al. 2018; Møller et al. 2014; Silvennoinen et al. 2012; Stenmarck et al. 2016). For instance, in Finland, previous studies indicate that questionnaires are suitable for collecting primary production and manufacturing waste data, 
whereas centralised data collection is a best practice for retail chains (Hartikainen et al. 2018; Silvennoinen et al. 2012). Food waste measurement methods and a quality standard for selecting the most suitable methods are presented in detail in this chapter.

The Finnish project presented in this chapter aims to feed results back to the food chain actors. The actors involved will discuss definitions and draft a national roadmap with national goals and measures for reducing Finnish food waste. The main emphasis of these efforts is on finding the most cost-effective and comprehensive measures at all steps of the food chain. The roadmap will evolve with the support of repeated food waste measurements and encourage key food chain stakeholders' active involvement. This chapter presents the overall structure of the national collaboration scheme in detail.

\section{Quality Standard for Food Waste Data Collection}

Building a system to monitor food waste levels calls for a quality standard to make the overall process and data collection transparent, more uniform and repeatable. As there is no agreement on food waste definitions and terminology, the quality standard also needs to address common terminology and definitions. The European Commission (2018a, b) is discussing minimum requirements and definitions for food waste data collection in the food chain. These decisions need close monitoring, and possible adjustments may be required to make the Finnish approach fulfil the Commission's future alignments.

Figure 16.1 demonstrates how the overall quality standard for food waste data collection in Finland will be divided into collaborative actions and food chain step-specific actions. Collaborative actions include: deciding on common definitions and system boundaries; following and adjusting to international agreements; and coordinating data collection from the different steps of the food chain. Collaboration between the actors in the food chain and key stakeholders is crucial to ensure uniform data collection.

Step-specific actions include: the most suitable data collections methods; possible specifications for the collected data (e.g. the level of detail 


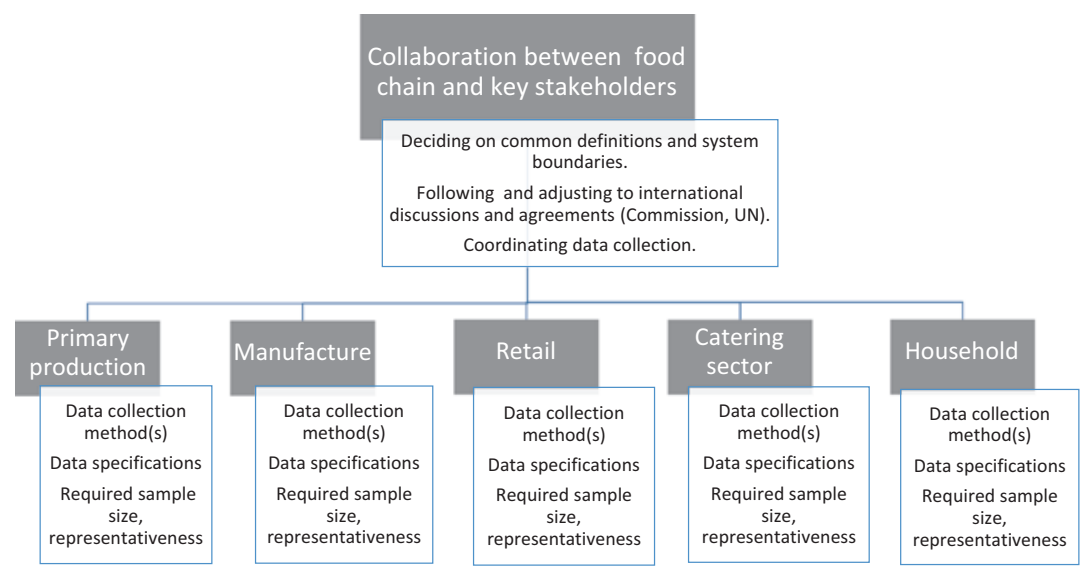

Fig. 16.1 Quality standard for food waste data collection in Finland

in the questions, supplementary questions); and the desired sample size and its representativeness. All these actions are discussed in detail in the following sections.

\section{Collaboration in Food Waste Data Collection}

Previous Finnish food waste studies (Hartikainen et al. 2018; Katajajuuri et al. 2014; Silvennoinen et al. 2014) and studies throughout Europe (Xue et al. 2017) have targeted different steps of the food chain, but they lack overall coordination throughout the food chain. For instance, Beretta et al. (2013) studied food waste in Switzerland's food chain. Their holistic approach improved the overall understanding of food waste in the Swiss food chain. Beretta et al. (2013) carried out a simultaneous examination of the entire food chain, because the cause of food waste could occur at a different step of the food chain from where it arises. For example, consumer behaviour and expectations often lead to food waste at different stages of the food chain. To avoid gaps in data collection and to gain a better understanding of the causal effects of food waste, it needs to be quantified along the food chain and not in "silos" as previously. 


\section{Definitions and System Boundaries}

There are no common food waste definitions or system boundaries (JRC 2017), and the definitions are still under discussion (European Commission 2016, 2018a, b). Luke and Ministry of Agriculture and Forestry of Finland are closely following the international discussion led by the European Commission, however, the level of data needed to benefit the Finnish food sector will be decided in Finland. For instance, it is still unclear whether the Commission will demand member countries to separate edible and inedible waste (parts such as peels and bones), yet there is wide agreement in Finland that the focus will be on monitoring and prevention of edible waste. Previous Finnish food waste data collection efforts have attempted to distinguish edible food waste from the rest of the food waste (Hartikainen et al. 2014; Silvennoinen et al. 2012). The Finnish aim is to collect data on edible and inedible food waste and to report both edible and inedible food waste to the Commission.

In the food waste hierarchy, the primary aim is that food should be eaten and, if impossible, fed to animals or used as raw material for non-food products (Papargyropoulou et al. 2014). Therefore, besides identifying the waste type (edible/inedible), it may also be important to monitor the destination of waste to evaluate how efficiently different food streams are used if food is not eaten. The destination may also define what is and is not included in waste estimates. For instance, the former EU project FUSIONS suggested a definition in which only food which finished up as waste (including landfill, sewerage, compost and biowaste) or as a low-value product (including its use as energy waste) should be classified as food waste (Stenmarck et al. 2016). The question of food being used for animal feed and how this is considered in the data collection and reporting process is an especially important aspect to consider. A study by the Joint Research Centre (JRC; the European Commission's science and knowledge service) (JRC 2017) suggests results vary greatly depending on whether or not studies include animal feed in waste estimations.

System boundaries between actors in the food chain and stakeholders also require discussion. The Commission has yet to specify the system 
boundaries. The FAO of the United Nations (2018a) states that only food initially produced for human consumption should be considered. This should be evident, but the FUSIONS project, for example, included waste streams such as cooking oil and coffee beans in their food waste quantification (Östergren et al. 2014). Additionally, in the FUSIONS project, the food system starts when a crop is ready for harvesting and animals/fish are sent for slaughter/to a fish processing plant and a cow is milked (Östergren et al. 2014). While this seems logical, the study ignores losses which may occur during animal rearing. Hartikainen et al. (2014) suggest meat losses during animal rearing due to animal death/rejection before slaughter can amount to $10 \%$ of beef and $3 \%$ of pork production. Moreover, it is not always evident whether all harvest losses are countable. For instance, if part of a crop is rotten or otherwise damaged in the field, it must be decided if it is to be counted as food waste or as a yearly crop loss.

There is some debate concerning which food waste would be avoidable if handled differently and which waste is unavoidable due to spoilage in the early stages of the food chain. In this respect, data collection should also consider dissimilarities between different steps of the food chain. For instance, the FAO (2018a) distinguishes the terminology it uses based on the steps of the food chain: if a product is spoiled before it becomes a final product or before it reaches the point of retail, it should be labelled as food loss (accidental waste), not as food waste. This is because spoilage is hard to avoid in the early steps of the food chain, whereas at the consumer level, spoilage could be a result of improper storage or some other cause. In this case, it should therefore be classified as food waste. However, there are also many cases in retail, the hospitality sector and households where food waste is hard to avoid, and thus would require significant effort to reduce food waste to zero. The use of the terms "avoidable" and "unavoidable" should therefore only be considered as a general guideline. This terminology should not limit the scope of the efforts to reduce food waste.

In the Finnish approach presented in this paper, we make no such distinctions and use "food waste" for all steps of the food chain. We recognise that dissimilarities between different steps should always be considered. 


\section{Coordinating Data Collection}

Data collection coordination requires that each step of the food chain uses similar definitions and system boundaries if possible. Additionally, decisions are needed on the data types and the level of detail which should be collected. While data is composed from each step of the food chain, coordination of the waste data throughout the food chain helps to identify possible trends in waste quantities throughout the food chain for different years. Detailed and comparable data is also important to better understand the causal relations of food waste and to set more specific measures to reduce food waste (Parfitt et al. 2010).

\section{Data Collection at Different Steps of the Food Chain}

Food waste data collection from the entire food chain must consider the special characteristics of the different steps of the food chain. Previous Finnish food waste studies have provided valuable information on the specific characteristics and most suitable data collection methods for each step (Hartikainen et al. 2018; Heikkilä et al. 2016; Katajajuuri et al. 2014; Silvennoinen et al. 2015; Wastestimator 2017). These characteristics include the type and number of actors, and existing waste data collection and reporting methods. In primary production and especially in households, there are many individual actors producing food waste, and therefore, more effort is needed to obtain a representative data sample from them. Retailers and food manufacturers collect waste data, but often this data is classified. The Finnish retail sector has published overall figures for waste in relation to food sales (PTY 2017). Moreover, only some large food manufacturers publish their waste quantities. Manufacturers processing animal by-products are required to report their waste quantities because of environmental permits. 


\section{Primary Production}

In 2017, there were around 48,600 farms in Finland (Luke 2018e). The vast majority produced food, and the rest produced animal feed and other products such as energy. Finnish food statistics send annual questionnaires to crop farmers concerning sold crops, but the statistics produced exclude harvest and post-harvest losses (Luke 2018e). However, there have been some Finnish case studies on food losses in primary production (Hartikainen et al. 2014, 2018; Luke 2018b). These case studies are mainly based on questionnaires and interviews. The case products include carrots, potatoes, wheat, rye, peas, strawberries, onions, white cabbage and lettuce. Nearly 2000 farms have replied to these questionnaires (Hartikainen et al. 2014, 2018; Luke 2018b). So far, there is no continuous data collection monitoring food waste in primary production.

Finnish farmers do not actually measure their food waste, but in Finnish studies, they claim to have a good understanding of their losses during and after harvests (Hartikainen et al. 2014). It is therefore reasonable to ask farmers about the waste produced using questionnaires and interviews. There have also been some field and stock composition measurements, and since the results of these tests have been similar to the questionnaires (Franke et al. 2016; Hartikainen et al. 2014), we consider questionnaires and interviews the best alternative compared to using highly resource-intensive field and stock measurements. In Finland, questionnaires and interviews concerning food have been successfully used for data collection from farmers (Hartikainen et al. 2014, 2018). Actual measurements would certainly give more exact information on losses, but the disadvantage is that on-farm crop loss measurements are time-consuming and laborious, and it would require numerous measurement points on several farms to obtain an overall understanding of primary production crop losses (Franke et al. 2016). Because there is a great deal of variation in the losses which occur for different crops, the demand for data collection becomes even higher.

Finnish food statistics gather annual meat and milk production data, collected mainly from slaughterhouses and the milk register 
(Luke 2018e). These statistics exclude rejected animals and milk losses. Commercial marine fisheries are an exception, and they compile statistics on the rejected catch (Luke 2018a). The Finnish Food Authority also collects data on numbers of dead/rejected cows and pigs. Additionally, waste treatment factories, such as Honkajoki, compile statistics on the animals and animal by-products they receive. Hence, there is some statistical data on losses. However, the existing statistics are insufficient for estimating all animal and fish production losses. There is therefore also a need to collect waste data concerning animal, fish and milk production. We consider the best available methods for this purpose to be questionnaires and interviews (Franke et al. 2016; Hartikainen et al. 2018).

Previous studies on primary production food losses have resulted in a somewhat low sample representativity, ranging from 8 to $27 \%$, with an average of around 10\% (Hartikainen et al. 2014, 2018). Because the desired sample size needs to be higher, we argue that questionnaires should be included in existing data collection processes. For instance, questions on crop production losses could be added to Luke's Statistical Services' annual crop production surveys. Table 16.1 lists needs that should be considered in future questionnaires (Hartikainen et al. 2014, 2018; Joensuu et al., forthcoming; Luke 2018b). One of the key findings of previous studies has been that questionnaires should be short and that the questions should be as easy as possible to answer. This improves the response rate and reduces the farmers' reporting load. It is also advisable to avoid terms such as "food waste" because these can be understood in different ways.

\section{Food Manufacturing}

Food manufacturing can be divided into meat processing, dairy production, drink production, baking, milling and starch production, vegetable processing and "other" (e.g. convenience food and sugar production). Finnish food manufacturing amounts to roughly 6 million tonnes annually. Dairy production is the largest by volume, followed by meat processing (Silvennoinen et al. 2012). The Finnish Food and 
Table 16.1 List of what needs to be considered in future questionnaires (Luke 2018b; Joensuu et al., forthcoming)

Time

Case products

What kind of question

Amount and type of questions

Response rate, motivation

Avoid blame
In new data collection methods, enough time should be allocated for planning the questionnaire, deciding on the desired sample, and analysing results

Case products should include products with the highest production volumes and different product types to cover different growing conditions (open field, greenhouse, etc.). It is unnecessary to include all product types if some case products represent others: e.g. blackcurrants can represent all bush-grown berries

To obtain a good response rate and good statistics, questions on the data collection form should be easily understandable. They should be unambiguous, and the instructions should be clear

There should not be too many questions because of the response burden. However, there should be enough questions for good statistics. Waste quantity, destination and cause should be ascertained to analyse the data

There should be an incentive for farmers to answer the questionnaire. The response rate can be improved by using incentives or diligently engaging in telephone calls, for example

Agricultural food waste reduction is difficult, and farmers rarely intend to cause waste. This is important to consider in both data collection and reporting

Drink Industries' Federation (ETL), which represents most of the Finnish food industry, has around 600 food and drink industry members, of which roughly $75 \%$ are small and medium-sized companies (ETL 2018).

Food manufacturers, especially large manufacturers, understand their material flows and waste quantities well (Hartikainen et al. 2014; Silvennoinen et al. 2012). However, only part of the Finnish food manufacturing industry is currently obligated to declare the amount 
and content of waste. This waste data is collected in the compliance monitoring data system, VAHTI (Berg 2016). The reporting obligation mainly concerns those manufacturers that process food containing meat products, since animal by-products are considered hazardous waste which requires proper disposal. Some other large producers also report their waste to VAHTI. However, bakeries and small-scale processors, for example, are missing from the VAHTI register. Moreover, waste quantities are usually reported as rough estimates in VAHTI, and it is therefore impossible to use the database to sort and categorise food waste data. Furthermore, only some food manufacturers declare their waste data annually in their corporate social responsibility (CSR) reports. This waste data is not based on commonly accepted methodologies, and it is therefore not entirely comparable. Existing statistical data is inadequate for estimating the amount of food being wasted, and in previous studies, food waste has therefore been evaluated with questionnaires sent to food manufacturers and from the CSR reports (Hartikainen et al. 2014; Silvennoinen et al. 2012).

In previous studies, the representativeness of the questionnaire samples has varied. In the study by Silvennoinen et al. (2012), 13 manufacturers responded, including large producers from dairy and meat, and convenience food production. Both sectors were well represented. However, fruit and vegetable processing was poorly represented. The study by Hartikainen et al. (2014) focused on fruit and vegetable processing and milling and included some large producers.

Based on Finnish experience, it is recommended that to promote systematic food waste data collection and to monitor future food waste, questionnaires and interviews should be used. These methods have been successfully used in Finland to obtain responses from large producers, so the expected response rate should be sufficient-especially if the largest manufacturers respond (Hartikainen et al. 2014; Silvennoinen et al. 2012).

\section{Retail}

There are two major retail store chains (totalling over $80 \%$ of the market) and one large chain (over 9\%) in Finland (PTY 2018). While the large retail chains in Finland regularly monitor their food waste, they 
are not obliged to declare the amount of food waste they produce. Nevertheless, in 2016, the Finnish retail chains voluntarily declared their total waste percentage in relation to overall sales (PTY 2017). Additionally, a Nordic research project evaluated retail and wholesale food waste in 2011 (Stenmarck et al. 2011). Representatives from retail stores, wholesale groups and the waste management sector in Sweden, Norway, Denmark and Finland were interviewed in the study. These interviews resulted in an overall figure for retail sector food waste. All the published retail sector data thus far has been aggregated into one figure. Any further division of food waste in the data has been considered by the sectors involved as classified information.

The future aim is to collect more detailed food waste data from retail stores to allow the monitoring of the waste streams concerning different product groups in the food chain. Success in sharing this classified information will depend on the retail sector's willingness to quantify and share this information.

\section{Catering Sector}

The catering sector includes schools, day care centres, hospitals and centres for the elderly, workplace restaurants, cafes and service stations, restaurants and hotels and fast food restaurants. In 2016, there were over 10,000 catering businesses in Finland (Mara 2018). Most were restaurants, hotels, cafeterias and service stations. However, schools serve the most meals annually-accounting for around a quarter of all the meals served.

The catering sector food waste can be divided into kitchen and buffet waste and plate leftovers (Silvennoinen et al. 2015). Some Finnish caterers monitor their waste, especially kitchen waste, but they rarely measure food waste in its entirety or publish waste data. Moreover, waste statistics lack data on catering waste. Although municipal waste (waste from caterers is classified as municipal waste) is monitored annually in Finland (Tilastokeskus 2015), there is no data concerning how much municipal waste comes from caterers and how much of it is food waste. There have been some studies in which caterers have kept food waste 
diaries and/or in which researchers have measured waste quantities in bins (e.g. Circwaste 2016; Silvennoinen et al. 2012; Wastestimator 2017). Over 130 catering sector organisations have participated in Finnish catering food waste studies. Most of the participants have been the catering departments of schools and day care centres. Generally, the sample is quite small and is not representative of the catering sector. Previous waste measurement periods have been quite short, mainly ranging from a day to a week, which also weakens the waste estimates. In the Circwaste project (2016), food waste data was collected for over 16 weeks (two periods of eight weeks), which gave a better overall understanding of waste in the participating caterers.

In the future, approaches to obtaining a comprehensive picture of food waste in the Finnish catering sector and to monitor food waste progress are needed. A study by Silvennoinen et al. (2012) demonstrated that waste quantities vary between different types of caterers, and data therefore needs to be collected from different caterers and areas. Ideally, the participating caterers should be chosen randomly. In Finland, it has been decided that future food diary measurements should have at least 20 caterers for each catering type, and waste measuring periods should last more than a week. This would enable the variation between different caterer types and within each type of caterer to be determined. However, if any conclusions on the direction of food waste quantities are to be drawn, the number of caterers participating in the study needs to be much higher. Such a sample is currently impossible, since it is time and resource consuming to persuade even a small number of caterers of each type to participate.

To improve estimates on food waste, Luke aims to send a questionnaire to more Finnish caterers (with a target response rate of 500 caterers) and aims to include questions such as "Do you measure your food waste?" and "Have you reduced your food waste? If so, by how much?" The term "food waste" can be used in the catering sector, since there are a common understanding and acceptance of its use (in contrast to primary production).

The catering sector is large and dispersed, and while many caterers already monitor their waste, most only partially understand their waste quantities. The main challenge is to motivate the management and 
kitchen personnel to measure kitchen and buffet food waste (Heikkilä et al. 2016) and encourage them to improve the measurement of plate leftovers. Previously, plate leftovers were measured by sorting through the waste in waste bins (Silvennoinen et al. 2012), and in the Circwaste project (2016), plate leftover measurement was tested with online scales installed under canteen bio-waste bins. Online reporting and measurement systems for kitchen and buffet waste as well as plate leftovers would make reporting and data handling easier and more efficient. These systems have already been tested in Finland. An example is the Circwaste project (2016): the results support the use of these online reporting and measurement systems. Besides online measurements, a questionnaire could increase the understanding of progress in food waste reduction amongst caterers.

\section{Households}

There are over 2.6 million households in Finland and the Finnish population is over 5.3 million. FinDiet studies household food consumption every five years. The study is based on a sample of Finnish households that report their food consumption in a diary study (THL 2018). These diary studies do not include possible food waste but only the quantity of consumed food. Moreover, there are no statistics on household food waste. While the quantity of municipal household waste is monitored annually (Tilastokeskus 2015), these statistics also lack data on how much food is wasted.

Studies on the quantity and composition of Finnish household food waste (Katajajuuri et al. 2014; Silvennoinen et al. 2012, 2013, 2014) are the only sources of household food waste data. The study methods used to gather this data have included: questionnaires (Silvennoinen et al. 2012, 2013), food waste diaries (Silvennoinen et al. 2012; Wastestimator 2017) and waste composition analyses (Silvennoinen et al. 2013; Wastestimator 2017). A comparison of these studies reveals that the results of the different methods vary. Interestingly, the totals are similar: around at 25 kilos of edible food waste per household per year (Silvennoinen et al. 2012; Wastestimator 2017), but the consistency of 
food waste is different when using waste composition analysis or a food waste diary (Katajajuuri et al. 2014; Silvennoinen et al. 2012, 2013, 2014; Wastestimator 2017). This is probably due to tendency of households to change their behaviour in a study setting. Additionally, while a waste bag analysis does not lead to the same problem, it cannot be used to track certain waste streams because liquids and waste disposed of down the drain or in the sewerage system is not included in waste bag analysis.

Food waste questionnaires are unsuitable for estimating the absolute quantity of household food waste because households do not clearly understand their waste streams. However, questionnaires can introduce useful supplementary information, since some questions indicate food waste indirectly. In a study by Silvennoinen et al. (2012, 2014), households answered a questionnaire and measured their waste quantities. It was found that the questions "How often does your household produce food waste?" and "Is it possible to reduce your household's food waste?" both indicated more food waste if the first answer was "frequently" and the second "yes". Hence, if questionnaires are repeated, they can also produce valuable insights into food waste monitoring. However, questionnaires alone are insufficient for monitoring food waste. Ideally, at least some questionnaire respondents should also participate in a diary study.

Food waste diaries are another important way to obtain a more comprehensive picture of waste composition (including liquids and waste disposed of in the sewerage system). A benefit of food waste diary studies is that they are not tied to a geographical area: households throughout Finland can participate in the study, allowing for a more representative sample. The challenges with the diary studies are in motivating different types of households to participate in them and ensuring that the households correctly measure their waste. In previous diary studies (Silvennoinen et al. 2012; Wastestimator 2017), households have received kitchen scales to conduct measurements. However, since this investment is costly and the measurements should be repeated periodically to monitor household food waste, an alternative method is needed. The FinDiet study is based on visual aids and ready-made lists of food portions (e.g. a piece of bread, etc.) to help households estimate 
the amount they eat (THL 2018). Similarly, visual aids and lists of food portions could be used to help households estimate their food waste. Moreover, to improve data reporting and handling, households could enter the data needed during diary studies directly online rather than by writing entries in a paper-based diary.

To monitor food waste and build a roadmap that comprehends household waste, the challenge is to obtain a representative sample of household food waste. Since none of the existing methods is perfect, food waste quantification could be based in all three methods to gain a more coherent picture of household food waste. Waste composition analysis could be repeated at certain intervals to measure food waste without the bias of households changing their behaviour. A questionnaire is also the simplest method of the three, and it could be a relatively easy way to obtain a large and representative sample. Questionnaires could therefore be used to compare different user groups, for example, based on the part of the country they live in.

Based on previous Finnish food waste studies (Silvennoinen et al. 2012, 2014; Wastestimator 2017), a rough estimate of the required sample for each method would be 1000 households responding to the questionnaire, over 200 households participating in the diary study and over 5000 households represented in waste composition analysis. Additionally, it is important that the samples represent all socio-demographic groups in the country.

\section{Implications for Developing a Food Waste Measuring and Management System}

\section{Engaging and Motivating Food Chain Actors to Provide Food Waste Data}

The Commission will require food waste data collection in the future (European Commission 2018a, b), which will probably increase the interest of the food chain actors in the topic. However, as long as the data collection is not obligatory for all food chain actors, the industry will not really be pressured to share data. In Finland, it will probably 
be challenging to obtain representative samples from all the steps in the food chain. Efforts are therefore needed to find ways to motivate and engage actors.

Luke's Statistical Services unit is a well-known for developing and distributing farmer questionnaires, and it is therefore suggested that it should distribute the questionnaires on food waste. Questions on crop losses could also be added to the annual crop production surveys run by Luke's Statistical Services. Telephone interviews are also needed to improve the response rate of future questionnaires. Producers may also consider information on losses to beneficial (providing benchmark data). Furthermore, short and clear questionnaires and prize draws have proved successful in obtaining more responses from farmers (Franke et al. 2016; Hartikainen et al. 2014, 2018).

A similar motivation strategy could be used for small and medium-sized food manufacturers as for primary producers. Larger manufacturers, retail sector chains and caterers need further motivation concerning the benefits national data collection could bring to them. For instance, as studies demonstrate (e.g. Beretta et al. 2013), detailed data collection along the food chain can increase the amount of information available on waste quantities and improve the food chain's overall performance. In general, food chain actors will be motivated as long as the data collection also benefits them.

Motivating household participation in obtaining a representative sample is also challenging. Past studies indicate that the sample of households is easily skewed when certain households respond to the questionnaire (Silvennoinen et al. 2014). Verbal motivation is therefore insufficient to obtain a representative sample. To improve household participation, households could be offered prize draws and monetary compensation as incentives to respond to a questionnaire and participate in diary studies.

\section{From Measurement to Management}

Food waste quantification provides important insights into food waste magnitudes throughout the food chain, which helps to orient action and identify the most effective ways of reducing food waste. Food waste 
monitoring throughout the food chain also helps to monitor overall food waste and ensures food that waste reduction actions lead to a reduction in the food chain's overall production of food waste. Food waste data collection should include questions on the reasons for food waste and on the uses of food waste to better connect causes with possible solutions.

Besides food waste monitoring, effective targets to reduce food waste and meet the reduction targets set by the Commission and UN need to be set. A national roadmap will therefore be established in Finland, in which the food chain stakeholders will agree upon the targets and measures needed to reduce food waste (Luke 2018c). The key to fruitful discussions concerning the building of the national roadmap is a collaborative approach to food waste data in which synergies are sought to reduce food waste efficiently in the entire food chain. This entails stakeholder meetings, workshops and other ways to promote active discussions between all actors. Detailed data can bring new insight into the causes of food waste. Additionally, since the causes of food waste may be located elsewhere from where the waste is produced, collaboration is essential to focus on its original causes and not merely treat its symptoms. In accordance with the waste hierarchy (Papargyropoulou et al. 2014), it is a priority to ensure that food is directed to human consumption.

\section{Conclusion and Next Steps}

Efficient food waste reduction requires food waste quantification that provides an insight into overall volumes and helps to reduce food waste throughout the food chain. The collection of food waste data should also include additional data on the causes of food waste, as well as food waste destinations and possible ways of reducing food waste. The data collection should also distinguish between edible and inedible food waste. Additionally, collaboration throughout the food chain and a system to collect food waste data at different steps of the food chain are needed.

Based on Luke's experience of food waste quantification in the food chain, Table 16.2 lists suggested methods for data collection and the 
Table 16.2 Data collection methods and the desired sample sizes for each step of the food chain

\begin{tabular}{|c|c|c|}
\hline Step of the food chain & Method & Desired sample size \\
\hline $\begin{array}{l}\text { Primary } \\
\text { production-crops }\end{array}$ & $\begin{array}{l}\text { Questionnaires: sent to } \\
\text { producers simultane- } \\
\text { ously with the crop } \\
\text { production survey } \\
\text { Interviews: } \\
\text { supplementary }\end{array}$ & $\begin{array}{l}\text { Producers representing } \\
30 \% \text { of the cultivation } \\
\text { area/case product }\end{array}$ \\
\hline $\begin{array}{l}\text { Primary production- } \\
\text { milk producers }\end{array}$ & $\begin{array}{l}\text { Questionnaires } \\
\text { Interviews: } \\
\text { supplementary }\end{array}$ & $\begin{array}{l}\text { Producers representing } \\
10 \% \text { of cultivation } \\
\text { area/case product }\end{array}$ \\
\hline $\begin{array}{l}\text { Primary production-ani- } \\
\text { mal husbandry, fishing, } \\
\text { fish cultivation }\end{array}$ & $\begin{array}{l}\text { Statistics: dead/rejected } \\
\text { animals, rejected } \\
\text { marine fishing catch } \\
\text { Questionnaires: other } \\
\text { animals/fish groups } \\
\text { Interviews: } \\
\text { supplementary }\end{array}$ & $\begin{array}{l}\text { Producers representing } \\
30 \% \text { of cultivation } \\
\text { area/case product }\end{array}$ \\
\hline Manufacturing & $\begin{array}{l}\text { Questionnaire } \\
\text { Interviews: } \\
\text { supplementary }\end{array}$ & $\begin{array}{l}\text { Producers representing } \\
30 \% \text { of production } \\
\text { volume//sector }\end{array}$ \\
\hline Retail & $\begin{array}{l}\text { Data collected by retail } \\
\text { groups }\end{array}$ & $\begin{array}{l}\text { The three largest retail } \\
\text { chains, representing } \\
\text { over } 90 \% \text { of sector } \\
\text { sales }\end{array}$ \\
\hline Caterers & $\begin{array}{l}\text { Food waste diary }(D) \\
\text { Questionnaire }(\mathrm{Q}): \\
\text { supplementary }\end{array}$ & $\begin{array}{l}\text { D: } 20 \text { caterers } / \text { caterer } \\
\text { type }=\text { over } 140 \text { caterers } \\
\text { Q: } 500 \text { caterers }\end{array}$ \\
\hline Households & $\begin{array}{l}\text { Online-questionnaire (Q): } \\
\text { supplementary } \\
\text { Waste composition analy- } \\
\text { sis (W) } \\
\text { Food waste diary (online) } \\
\text { (D) }\end{array}$ & $\begin{array}{l}\text { Q: } 1000 \text { households } \\
\text { W: } 5000 \text { households } \\
\text { D: } 200 \text { households }\end{array}$ \\
\hline
\end{tabular}

desired sample sizes for each step of the Finnish food chain. Food waste data collection is voluntary, and the desired sample sizes are ambitious but realistic. However, it is most likely that only the retail sample sizes will prove to be statistically significant. Supplementary methods are therefore suggested (Table 16.2). In the future, there should be more emphasis on incentives and other means (e.g. regulation) to improve 
the sample sizes. Moreover, while the results will be further studied and possible uncertainties addressed, all final values will have an uncertainty interval. This uncertainty needs to be clearly stated to avoid any misinterpretations.

Using the Finnish food waste quantification system, the aim is to further test the data collection between 2018 and 2020 and calculate a baseline year for the start of food waste monitoring from which point forward the monitoring will be repeated at certain intervals. Besides the data collection, it is equally important to improve collaboration in the food chain and make the data collection transparent and uniform. The aim is also to hold workshops and meetings to discuss efficient means of reducing food waste and to establish a national roadmap in which stakeholders determine targets and ways of reducing food waste in the food chain.

\section{References}

Beretta, C., Stoessel, F., Baier, U., \& Hellweg, S. (2013). Quantifying food losses and the potential for reduction in Switzerland. Waste Management, 33(3), 764-773.

Berg, J. (2016). ETL:n jäte- ja sivuvirtaselvitys 2016. Elintarviketeollisuusliitto (ETL). http://www.etl.fi/media/aineistot/raportit-ja-katsaukset/etl-jate_ja_ sivuvirtaselvitys_2016.pdf. Accessed on 27.2.2019.

Circwaste. (2016). CIRCWASTE-Towards a circular economy in Finland. Finnish Environment Institute. http://www.syke.fi/en-US/Research_ Development/Research_and_development_projects/Projects/CIRCWASTE_ Towards_Circular_Economy_in_Finland. Accessed on 27.2.2019.

ETL. (2018). ETL edustaa laajasti elintarviketeollisuutta. Elintarviketeollisuusliitto. http://www.etl.fi/jasenet.html. Accessed on 27.2.2019.

European Commission. (2016). EU Platform on food losses and food waste terms of reference (ToR). European Commission Directorate-General for Health and Food Safety. https://ec.europa.eu/food/sites/food/files/safety/docs/fw_ eu-actions_flw-platform_tor.pdf. Accessed on 27.2.2019.

European Commission. (2018a). EU actions against food waste. European Commission. https://ec.europa.eu/food/safety/food_waste/eu_actions_en. Accessed on 27.2.2019. 
European Commission. (2018b). Food waste monitoring-Update. EU Platform on food losses and food waste. https://ec.europa.eu/food/sites/ food/files/safety/docs/fw_eu-platform_20181206_flw_pres-03.pdf. Accessed on 27.2.2019.

FAO. (2018a). Food loss and food waste. Food and Agriculture Organization of the United Nations. http://www.fao.org/food-loss-and-food-waste/en/. Accessed on 27.2.2019.

FAO. (2018b). Technical platform on the measurement and reduction of food loss and waste. Food and Agriculture Organization of the United Nations. http://www.fao.org/platform-food-loss-waste/food-waste/definition/en/. Accessed on 27.2.2019.

Franke, U., Hartikainen, H., Mogensen, L., \& Svanes, E. (2016). Food losses and waste in primary production: Data collection in the Nordic countries. Nordic Council of Ministers, Nordic Council of Ministers Secretariat. $\quad$ http://norden.diva-portal.org/smash/record.jsf?pid=diva2\%3A945862\&dswid=-9860. Accessed on 27.2.2019.

Hartikainen, H., Kuisma, M., Pinolehto, M., Räikkönen, R., \& Kahiluoto, H. (2014). Food waste in primary production (orig. Ruokahävikki alkutuotannossa ja elintarvikejalostuksessa) Foodspill 2 project report, MTT Report 170. http://jukuri.luke.fi/handle/10024/485067. Accessed on 27.2.2019.

Hartikainen, H., Mogensen, L., Svanes, E., \& Franke, U. (2018). Food waste quantification in primary production-The Nordic countries as a case study. Waste Management, 71, 502-511.

Heikkilä, L., Reinikainen, A., Katajajuuri, J.-M., Silvennoinen, K., \& Hartikainen, H. (2016). Elements affecting food waste in the food service sector. Waste Management, 56, 446-453.

Joensuu, K., Hartikainen, H., Karppinen, S., Jaakkonen, A.-K., \& Kuoppaaho, M. (forthcoming). Developing statistical food waste data collection on the primary production of fruit and vegetables. To be submitted.

JRC. (2017). Food waste accounting: Methodologies, challenges and opportunities. Joint Research Centre Technical Reports, European Commission. http:// publications.jrc.ec.europa.eu/repository/bitstream/JRC109202/jrc_technical_report_food_waste_rev_2_online_final.pdf. Accessed on 27.2.2019.

Katajajuuri, J.-M., Silvennoinen, K., Hartikainen, H., Heikkilä, L., \& Reinikainen, A. (2014). Food waste in the Finnish food chain. Journal of Cleaner Production, 73, 322-329.

Luke. (2018a). Commercial marine fishery 2017. Natural Resources Institute Finland. http://stat.luke.fi/en/commercial-marine-fishery. Accessed on 27.2.2019. 
Luke. (2018b). Data collection on food waste statistics in plant production farms in Finland. Natural Resources Institute Finland. https://www.luke.fi/en/ projects/ruokajate-eurostat/. Accessed on 27.2.2019.

Luke. (2018c). EU alkaa kerätä tietoa ruokajätteestä - Suomessa seurannan kehittäminen jo vauhdissa. Natural Resources Institute Finland. https:// www.luke.fi/uutiset/eu-alkaa-kerata-tietoa-ruokajatteesta-suomessa-seurannan-kehittaminen-jo-vauhdissa/. Accessed on 27.2.2019.

Luke. (2018d). Homepage of Natural Resources Institute Finland (Luke). Natural Resources Institute Finland. https://www.luke.fi/en/. Accessed on 27.2.2019.

Luke. (2018e). Structure of agricultural and horticultural enterprises. http://stat. luke.fi/en/structure-of-agricultural-and-horticultural-enterprises. Accessed on 27.2.2019.

Mara. (2018). Ravintolayritykset Suomessa. Matkailu- ja ravintolapalvelut. https://mara.fi/ravintoloiden-maaran-kehittyminen. 27.2.2019.

Møller, H., Hanssen, O. J., Gustavsson, J., Östergren, K., Stenmarck, Å., \& Dekhtyar, P. (2014). Report on review of (food) waste reporting methodology and practice. FUSIONS report. http://www.eu-fusions.org/index.php/ download?download=7:report-on-review-of-food-waste-reporting-methodology-and-practice. Accessed on 27.2.2019.

Östergren, K., Gustavsson, J., Bos-Brouwers, H., Timmermans, T., Hansen, O. J., Møller, H., et al. (2014). Definitional framework for food waste, full report. FUSIONS project. https://www.eu-fusions.org/phocadownload/ Publications/FUSIONS\%20Definitional\%20Framework\%20for\%20 Food\%20Waste\%202014.pdf. Accessed on 27.2.2019.

Papargyropoulou, E., Lozano, R., Steinberger, J. K., Wright, N., \& bin Ujang, Z. (2014). The food waste hierarchy as a framework for the management of food surplus and food waste. Journal of Cleaner Production, 76, 106-115.

Parfitt, J., Barthel, M., \& Macnaughton, S. (2010). Food waste within food supply chains: Quantification and potential for change to 2050. Philosophical Transactions of the Royal Society B: Biological Sciences, 365(1554), 3065-3081.

PTY. (2017). Ruokahävikin vähentäminen kaupoissa. Päivittäistavarakauppa ry (Finnish Grocery Trade Association). https://www.pty.fi/ruokahaevikki/. Accessed on 27.2.2019.

PTY. (2018). Päivittäistavarakaupan tilastot. Markkinaosuudet 2017. Päivittäistavarakauppa ry (Finnish Grocery Trade Association). https://www. pty.fi/julkaisut/tilastot/. Accessed on 27.2.2019. 
Silvennoinen, K., Heikkilä, L., Katajajuuri, J.-M., \& Reinikainen, A. (2015). Food waste volume and origin: Case studies in the Finish food service sector. Waste Management, 46, 140-145.

Silvennoinen, K., Katajajuuri, J.-M., Hartikainen, H., Heikkilä, L., \& Reinikainen, A. (2014). Food waste volume and composition in Finnish households. British Food Journal, 116(6), 1058-1068.

Silvennoinen, K., Koivupuro, H.-K., Katajajuuri, J.-M., Jalkanen, L., \& Reinikainen, A. (2012). Ruokahävikki suomalaisessa ruokaketjussa. Foodspill 2010-2012 -hankkeen loppuraportti. MTT Raportti 41. http://www.mtt. fi/mttraportti/pdf/mttraportti41.pdf. Accessed on 27.2.2019.

Silvennoinen, K., Pinolehto, M., Korhonen, O., Riipi, I., \& Katajajuuri, J.-M. (2013). Kauppakassista kaatopaikalle, ruokahävikkikotitalouksissa: Kuru-hankkeen loppuraportti. MTT Raportti 104. http://jukuri.luke.fi/handle/10024/481106. Accessed on 27.2.2019.

Stenmarck, Å., Hanssen O. J., Silvennoinen K., Katajajuuri J.-M., \& Werge, M. (2011). Initiatives on prevention of food waste in the retail and wholesale trades. Nordic Council of Ministers. http://www.norden.org/en/publications/publikationer/2011-548. Accessed on 27.2.2019.

Stenmarck, Å., Jensen, C., Quested, T., \& Moates, G. (2016). Estimates of European food waste levels. FUSIONS EU project. www.eu-fusions.org/ phocadownload/Publications/Estimates $\% 20$ of $\% 20$ European $\% 20$ food $\% 20$ waste\%20levels.pdf. Accessed on 27.2.2019.

THL. (2018). FinRavinto-tutkimus. National Institute for Health and Welfare (Terveyden ja hyvinvoinnin laitos). https://thl.fi/fi/tutkimus-ja-kehittaminen/tutkimukset-ja-hankkeet/finravinto-tutkimus. Accessed on 27.2.2019.

Tilastokeskus. (2015). Jätetilasto. Tilastokeskus. http://www.stat.fi/til/jate/. Accessed on 27.2.2019.

UN. (2016). Goal 12: Ensure sustainable consumption and production patterns. United Nations. http://www.un.org/sustainabledevelopment/sustainable-consumption-production/. Accessed on 27.2.2019.

van Herpen, E., van der Lans, I., Nijenhuis, M., Holthuysen, N., Kremer, S., \& Stijnen, D. (2016). Consumption life cycle contributions: Assessment of practical methodologies for in-home waste measurement. EU Horizon 2020 REFRESH. Wageningen: Wageningen University and Research. https:// eu-refresh.org/sites/default/files/D 1.3\%20final $\% 20$ report $\% 20$ Nov $\% 20$ 2016.pdf. Accessed on 27.2.2019. 
Wastestimator. (2017). Wastestimator hanke. Natural Resources Institute Finland. https://www.luke.fi/ravintolafoorumi/wp-content/uploads/sites/4/2016/10/ Wastestimator-posteri.pdf. Accessed on 27.2.2019.

Xue, L., Liu, G., Parfitt, J., Liu, X., Van Herpen, E., Stenmarck, Å., et al. (2017). Missing food, missing data? A critical review of global food losses and food waste data. Environmental Science \& Technology, 51(12), 6618-6633.

Open Access This chapter is licensed under the terms of the Creative Commons Attribution 4.0 International License (http://creativecommons. org/licenses/by/4.0/), which permits use, sharing, adaptation, distribution and reproduction in any medium or format, as long as you give appropriate credit to the original author(s) and the source, provide a link to the Creative Commons license and indicate if changes were made.

The images or other third party material in this chapter are included in the chapter's Creative Commons license, unless indicated otherwise in a credit line to the material. If material is not included in the chapter's Creative Commons license and your intended use is not permitted by statutory regulation or exceeds the permitted use, you will need to obtain permission directly from the copyright holder.

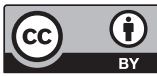

